\title{
Competitiveness and Determining Factors of Indonesian Tea Export Volume in the World Market
}

\author{
Hendi Nursodik $^{1 *}$, Siswanto Imam Santoso ${ }^{2}$, Suryani Nurfadillah ${ }^{2}$ \\ Agribusiness Study Program, Faculty of Animal and Agricultural Sciences, Diponegoro University, \\ Semarang, Central Java
}

Received: 7 April 2021; Revised: 18 October 2021; Accepted: 22 October 2021

\begin{abstract}
Indonesia is one of the world's tea exporters, but the decline in the volume and value of its exports to date continues to occur. This study aims to 1) analyze the production trend and export volume of Indonesian tea. 2) analyze Indonesian tea competitiveness in the International market compared to other exporter countries (China, India, Kenya, Sri Lanka, and Vietnam). 3) analyze the determining factors of Indonesia's tea export volume to 7 major destination countries (Malaysia, Russia, Pakistan, USA, Germany, Poland, and Australia). The analysis methods used are simple linear regression, Revealed Comparative Advantage (RCA), Trade Specialization Ratio (TSR), and data panel regression. The results showed that the production and volume of Indonesian tea export will decrease every year. Indonesian tea has a very strong comparative competitiveness, but still below India, Kenya, Sri Lanka, and Vietnam. Indonesia tends to be an exporter of tea to the international market at the stage of export expansion. Factors determining the volume of Indonesian export are Indonesian tea production, the population of importer countries, real GDP per capita of importer countries, level of trade openness of importer countries, and importer countries' inflation rate.
\end{abstract}

Keywords: competitiveness; exports; panel; data; tea

\section{How to cite:}

Nursodik, H., Santoso, S. I., \& Nurfadillah, S. (2021). Competitiveness and Determining Factors of Indonesian Tea Export Volume in the World Market. Habitat, 32(3), 163-172. https://doi.org/10.21776/ub.habitat.2021.032.3.18

\section{Introduction}

International trade is the exchange of goods or services between countries based on voluntary, mutual agreement and mutual benefit. International trade conducted by Indonesia is one of them in tea commodities derived from the plantation sub-sector. Tea is a commodity that originated in China and now ranks as the second most consumed beverage globally after water consumption reaching 3 billion cups per day (Voora et al., 2019). The increasing demand for world tea is due to increased demand from China, India, and other developing countries (Deka \& Goswami, 2021).

World tea production increased significantly in 2013 by $6 \%$ to 5.07 million tons (Narmada et al., 2020). World tea production in 2017 even reached 5.98 million tons of which

${ }^{*}$ Correspondence Author.

E-mail: hendinursodik@gmail.com

Phone: +62-822-4073-5690 about $35 \%$ of them were exported or worth US\$ 8 billion (Voora et al., 2019). Black tea is the largest contributor in terms of production and consumption, while in the future, the estimated demand for green tea and special tea varieties will continue to increase (Deka \& Goswami, 2021). Countries acting as world tea exporters include China (15.10\%), Sri Lanka (14.41\%), Kenya (13.99\%), India (10.75\%), and Vietnam (4.33\%), Argentina (3.59\%), and Indonesia (2.98\%) (Directorate General of Plantation Indonesia, 2019). Tea production has significantly contributed to the economy in China, India, Sri Lanka, Indonesia, Kenya, and others (Wal, 2008).

The volume of Indonesian tea exports to the world market in the last two decades has decreased. This can be seen from the export volume in 2001 of 98,968 tons to 42,663 tons in 2019 (Trademap, 2021). The decrease in export volume is in line with Indonesia's tea production decreasing every year. Indonesia's tea production decreased by $-0.63 \%$ per year in $2000-2018$, or 162,586 tons in 2000 to 137,803 tons in 2019 (FAO, 2021). The same is true of its export value. 
The export value of Indonesian tea in 2010 was US\$ 178,549 thousand and after that continued to decline until 2019, only US\$ 92,347 thousand (Trademap, 2021).

As the world's tea exporter, Indonesia always faces problems and challenges in exporting tea to the main destination countries. Indonesia's main tea export destinations are Malaysia, Russia, Pakistan, the United States, Germany, Poland, and Australia. The increasing competition of the tea market in the world market requires Indonesia to continue to innovate to be highly competitive to strengthen its market share.

Research on the competitiveness of Indonesian tea in the international market conducted by Ramadhani (2013) found that Indonesia is not competitive in importing tea, meet domestic and export needs, and has a strong competitiveness. Real exchange rates and real prices significantly affect the competitive position, while tea production has no significant effect on Indonesian tea's competitiveness in the international market.

Research conducted Chadhir (2015) concluded the real exchange rate of rupiah against the US dollar and the real price of international tea had a positive effect, while the UK's real GDP negatively influenced the volume of Indonesian tea exports to the UK. While other studies only examine the competitiveness of Indonesian tea without analyzing the factors that affect its exports (Khaliqi et al., 2020; Nayantakaningtyas et al., 2017; Suprihatini, 2005).

The difference in this research is that in addition to being reviewed the competitiveness of Indonesian tea, it will also be discussed the influence of inflation and trade openness of importer countries on Indonesian tea's export volume. The purpose of this study is 1) analyzing the production trend and export volume of Indonesian tea. 2) analyze the competitiveness of Indonesian tea in the world market. 3) analyze the determining factors of Indonesia's tea export volume to 7 major destination countries (Malaysia, Russia, Pakistan, USA, Germany, Poland, and Australia).

\section{Theoritical Underpinning}

International trade occurs for at least two reasons, that is countries are different from each other and countries want to achieve economies of scale in the production process (Krugman et al., 2018). A country will produce certain commodities effectively until it reaches economies of scale and does not force all commodities to be produced in its country. The country then specializes in profiting in international trade. Theories of international trade have been widely presented by world economists including Adam Smith's theory of absolute advantage, David Ricardo's theory of comparative advantage, and the theory of factors of production from Eli Heckscher and Bertil Ohlin.

The theory of comparative advantage states that international trade can occur even if a country does not have an absolute advantage over a commodity. A country can feel the benefits of international trade can be obtained by exporting commodities that have the greatest relative advantage and importing commodities with the smallest relative advantages (Pugel, 2016). This can provide a solution for countries that do not have an absolute advantage over other countries.

Comparative competitiveness theory is used to compare a country's ability with other countries in exporting. A country's commodities can be said to have comparative competitiveness if the market share of export commodities exceeds the total share of commodity markets in trade around the world (Content \& Frenken, 2016). Determinants of export competitiveness include real effective exchange rates, GDP, productivity and labor costs, trade liberalization, and trade barriers (Paul \& Dhiman, 2021).

Exports carried out by a country certainly have a variety of inhibitory factors and supporting factors that always accompany it. Exports are influenced by the level of economic openness, inflation, exchange rate, and economic size (Abidin et al., 2013). In addition, exports are also influenced by GDP, population, export prices, and amount of production (Bassa \& Goshu, 2019; Bekele \& Mersha, 2019)

The level of trade openness means that the country is increasingly open with trade liberalization and one of the positive impacts is that it can increase exports. The level of trade openness has theoretically affected economic growth (Anyanwu, 2014). Trade openness indicates the reduction of trade barriers in the form of tariffs and non-tariffs so that the mobility of commodity transactions between countries is higher. Factors that cause the increasing openness of a country's trade are effective government, quality of supportive regulation, and the existence of the rule of law (Ngouhouo et al., 2021).

Inflation is caused by three things, namely the high level of aggregate demand rather than the 
supply of available goods, the effect of a continuous increase in production costs, and prolonged conflicts (Carvalho et al., 2017). The high cost of producing export commodities can certainly disrupt the flow of exports, causing losses for exporters and in the long run can disrupt the economic conditions of a country.

\section{Research Methods}

The method used in this study is the descriptive quantitative method. The type of data used is secondary data. The main data sources come from United Nations Commodity Trade Statistic Database (UN Comtrade), Trade Statistics for International Business Development (Trademap), Food and Agriculture Organization (FAO), Indonesian Ministry of Agriculture, Directorate General of Indonesian Plantations, World Bank, and other relevant literature support this research. In this study, the tea is HS0902 (green tea and black tea are flavoured or not flavoured).

Comparative competitiveness analysis tools used are Revealed Comparative Advantage (RCA) and Trade Specialization Ratio (TSR), calculated in $2004-2019$. Regression panel data is used to analyze the determining factors of Indonesia's tea export volume using time series 2000 - 2019 data and cross-section 7 major export destinations of Indonesia tea, namely Malaysia, Russia, Pakistan, United States, Germany, Poland, and Australia.

\subsection{Trend Analysis}

Analysis of the production trend and export volume of Indonesian tea is done using simple linear regression. The year used is $2000-2019$ and will be analyzed trend until 2024. The equation can be formulated as follows:

$$
\mathrm{Y}=\mathrm{a}+\mathrm{bx}
$$

Where: Y, production / volume of Indonesian tea; $\mathrm{a}$, constants; $\mathrm{b}$, regression coefficient of time change; $x$, trend.

\subsection{Competitiveness Analysis}

Revealed Comparative Advantage (RCA) is an analytical method used to determine a country's comparative advantage in a particular export commodity. The RCA formula is as follows:

$$
\mathrm{RCA}=\frac{\mathrm{X}_{\mathrm{ijt}} / \mathrm{X}_{\mathrm{it}}}{\mathrm{X}_{\mathrm{wjt}} / \mathrm{X}_{\mathrm{wt}}}
$$

Where: $X_{\mathrm{ijt}}$, value of the country's exports $i$ commodity $j$ year $t$; $X_{i t}$, value of the country's exports i year $t$; $X_{w j t}$, value of the world's exports of commodities $\mathrm{j}$ year $\mathrm{t}$; $\mathrm{X}_{\mathrm{wt}}$, total world commodity exports year $t$.

If the RCA index is more than 1 , then the country has a higher share of exports than the world average or has a comparative advantage, if the RCA index is less than 1, then the country does not have a comparative advantage. It was further elaborated by Wang (2015) that comparative advantages were further divided into very strong advantages $(\mathrm{RCA}>2.5)$, strong advantages $(1.25$ $\leq \mathrm{RCA} \leq 2.5)$, moderate advantages $(0.8 \leq \mathrm{RCA}<$ $1.25)$, and weak losses (RCA $<0.8)$.

Trade Specialization Ratio (TSR) is a comparative competitiveness analysis tool to find out if the country is more of an exporter or importer. The TSR analysis formula can be written as follows:

$$
\mathrm{TSR}=\frac{X_{\mathrm{ijt}}-M_{\mathrm{ijt}}}{X_{\mathrm{ijt} t}+M_{\mathrm{ijt}}}
$$

Where: Xijt, the export value of the country $i$ komodutas $\mathrm{j}$; Mijt, the value of the country's imports i commodity $j$.

TSR values range from -1 to 1 . If the TSR value is more than 0 , then the country tends to be an exporter. If the TSR value is less than 0 , then the country tends to be an importer. The TSR method is also used to analyze the product cycle in trading into 5 stages, namely:

1) Introduction stage, (-1 to -0.5$)$;

2) Import substitution stage, (0.0 to 0.0$)$;

3) Expansion stage, (0.01 to 0.8$)$;

4) Maturity stage, (0.8 to 1.0$)$;

5) Re-import stage, if value decreases (1 to 0.0 ).

\subsection{Data Panel Regression}

Data panel regression is a regression that combines time series and cross-Section data. Panel data provides more information, less colinearity, and model estimation will become more efficient (Gujarati \& Porter, 2009). The regression of panel data in this study was used to analyze the determining factors of Indonesia's tea export volume to 7 major destination countries. The regression model in this study was formulated as follow:

Ln_VOL ${ }_{\text {it }}=\beta_{0}+$ Ln_PROD ${ }_{i t}+$ Ln_PRICE $_{i t}+$ Ln_PO $\mathrm{P}_{\mathrm{it}}+{ }_{\mathrm{Ln}} \mathrm{GDP}_{\mathrm{it}}+\mathrm{Ln}_{-} \mathrm{OPE}_{\mathrm{it}}+\mathrm{INF}_{\mathrm{it}}+\epsilon_{\mathrm{it}}$

Where: $\beta_{0}$, constants; $\mathrm{Ln}_{-} \mathrm{VOL}_{\mathrm{it}}$, volume of Indonesian tea export to country $\mathrm{i}$ in the year $\mathrm{t}$ (Kg/year); Ln_PROD ${ }_{i t}$, Indonesian tea production 
year $\mathrm{t}\left(\mathrm{Kg} /\right.$ year); Ln_PRICE $\mathrm{it}_{\mathrm{it}}$, price of Indonesian tea exports to country $\mathrm{i}$ year $\mathrm{t}$ (US\$/Kg); $\mathrm{Ln}_{\mathrm{P}} \mathrm{POP} \mathrm{it}_{\mathrm{it}}$, population of the country $\mathrm{i}$ year $\mathrm{t}$ (people/year); Ln_GDP ${ }_{i t}$, real GDP per capita of the country i year t (US\$/year); Ln_OPE openness of the country i year $t(\% /$ year $) ; \mathrm{INF}_{\text {it }}$, inflation rate of the country i year $\mathrm{t}(\% / \mathrm{year})$; and $\epsilon_{\mathrm{it}}$, residual.

\section{Results and Discussions}

\subsection{Analysis of Indonesian Tea Export Production Trend and Volume}

Based on Indonesia's tea production trends in the next 5 years, it is predicted to continue to decline and in 2024 will touch the figure of 129,492 tons. The equation shows that every 1 year, there will be a decrease in the production of 1,598 tons. This is in line with the decreasing area of tea plantations that decrease due to land transfer for infrastructure projects (Nugrahaningrum et al., 2020). Tea plantations are also converted into plantation areas of other commodities such as palm oil or vegetables. (Nurunisa \& Baga, 2012).

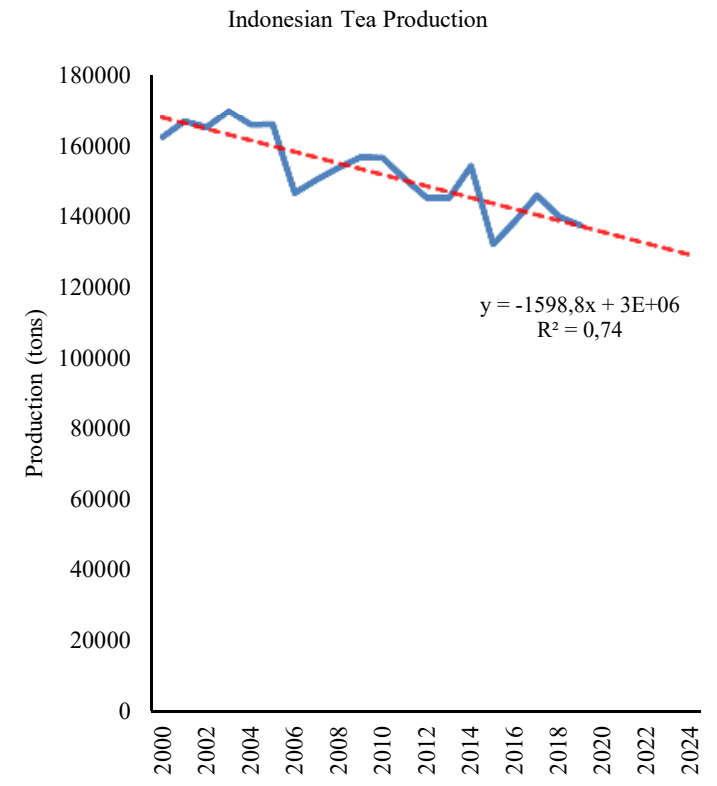

Figure 1. Indonesian tea production trend Source: Directorate General of Plantation Indonesia, 2019 (processed).

Export demand is the amount of domestic production minus domestic consumption coupled with the previous year's stock. The trend analysis shows that Indonesia's tea export volume is predicted to always decrease over the next 5 years. From the equation, it is known that if the decline is considered constant, every 1 year the volume of Indonesian tea exports will decrease by 3,201 tons. Indonesia's tea export volume in 2024 will continue to decline to 33,141 tons only.

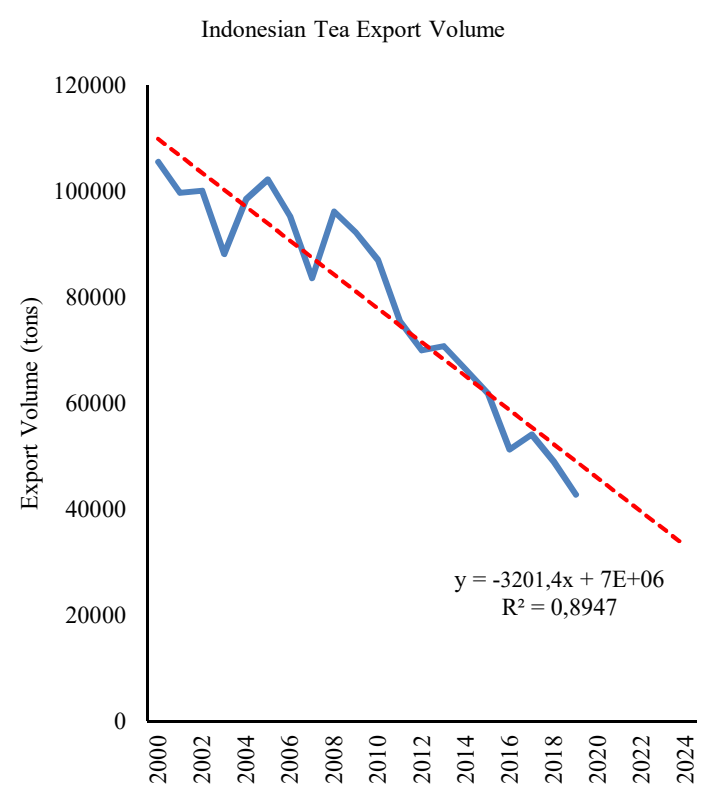

Figure 2. Indonesian tea export volume trend Source: UN Comtrade, 2020 (processed).

\subsection{Revealed Comparative Advantage (RCA)}

The average RCA index of Indonesian tea (table 1) in 2004 - 2019 amounted to 2.55, which means that tea commodities have a very strong comparative competitiveness in the international market. The value of RCA Indonesia is quite volatile and experiencing a downward trend. Indonesia's RCA value is still lower when compared to competitors from world tea exporting countries such as Sri Lanka, Kenya, India, Vietnam, and Vietnam. China's RCA value of 1.51 includes strong competitiveness but relatively low compared to other exporters, including Indonesia. This is because the export value of tea is lower than the export value of other commodities. China is the world's largest tea producer and exporter, reaching 2,278 million or $42.94 \%$ of its total tea production in 2015 (Zhi et al., 2018).

Kenya's highest RCA average index is 496.10, which means it has a very strong competitiveness. This can happen because tea is Kenya's main export commodity. According to Fuady et al. (2017) Kenya's main exports come from the agricultural sector of coffee, tea, and cut flowers. Sri Lankan tea RCA Index (334.49), India (7.46), and Vietnam (5.34). Overall, the comparative competitiveness of the largest tea exporter countries in $2004-2019$ is experiencing a downward trend. 
Table 1. RCA Tea Index (HS 0902) Indonesia and Competing Countries in the International Market

\begin{tabular}{ccccccc}
\hline \multirow{2}{*}{ Year } & \multicolumn{7}{c}{ Tea Exporter Countries } \\
\cline { 2 - 7 } & Indonesia & China & Sri Lanka & Kenya & India & Vietnam \\
\hline $2004-2007$ & 3,88 & 1,72 & 374,37 & 496,70 & 10,78 & 8,67 \\
$2008-2011$ & 2,84 & 1,28 & 392,85 & 505,04 & 7,64 & 6,42 \\
$2012-2015$ & 1,99 & 1,34 & 346,46 & 478,35 & 5,68 & 3,97 \\
$2016-2019$ & 1,49 & 1,69 & 224,28 & 504,32 & 5,74 & 2,31 \\
\hline Average & 2,55 & 1,51 & 334,49 & 496,10 & 7,46 & 5,34 \\
\hline
\end{tabular}

Source: Trademap, 2021 (processed).

\subsection{Trade Specialization Ratio (TSR)}

Based on TSR analysis (table 2) in general in the period $2004-2019$ Indonesia acts as the world's tea exporter and is at the stage of export growth or expansion. The value of TSR Indonesia in $2004-2010$ above 0.80 indicates the export of Indonesian tea in the International market has reached the stage of export maturity. However, after that year, Indonesia returned to the stage of growth or expansion of exports.
The return of tea exports to the export expansion stage is due to Indonesia's declining export volume, which affects the value of its exports. Also, its low productivity adds to the problem. Factors of low productivity of Indonesian tea are unsuitable climatic conditions, lack of good crop fertilization, suboptimal land management, lack of good cooperation between policyholders, and poorly supported soil physical properties (Ishak et al., 2019).

Table 2. TSR Tea Value (HS 0902) Indonesia and Competitor Countries in International Market

\begin{tabular}{ccccccc}
\hline \multirow{2}{*}{ Year } & \multicolumn{7}{c}{ Tea Exporter Countries } \\
\cline { 2 - 7 } & Indonesia & China & Sri Lanka & Kenya & India & Vietnam \\
\hline $2004-2007$ & 0,88 & 0,97 & 0,96 & 0,96 & 0,87 & 0,97 \\
$2008-2011$ & 0,81 & 0,92 & 0,95 & 0,98 & 0,87 & 0,95 \\
$2012-2015$ & 0,67 & 0,87 & 0,98 & 0,97 & 0,87 & 0,93 \\
$2016-2019$ & 0,56 & 0,83 & 0,97 & 0,98 & 0,90 & 0,84 \\
\hline Average & 0,73 & 0,90 & 0,96 & 0,97 & 0,88 & 0,92 \\
\hline
\end{tabular}

Source: Trademap, 2021 (processed).

The declining value of TSR is also due to the increasing volume of Indonesian tea imports. Recorded in 2004, the volume of Indonesian tea imports was only 3,924 tons, while in 2019 it increased rapidly to 16,326 tons or an increase of $13.9 \%$ per year (Trademap, 2021). per year. While the export value in 2004 amounted to the US \$ 5,531 thousand increased to the US \$ 36,037 thousand or an increase of $16.9 \%$ per year (Trademap, 2021).

TSR values from competing countries in the period 2004 - 2019 include China (0.90), Sri Lanka (0.96), Kenya (0.97), India (0.88), and Vietnam (0.91), indicating that tea exports to the international market have reached the stage of export maturity. China as the world's leading exporter of tea has a high TSR value, but its value tends to decline. This is because in the period 2002 - 2019, although China's tea exports in the international market increased rapidly by a value of $10.5 \%$, the increase in imports was much higher by $30.4 \%$ (Trademap, 2021).

Kenya's highest RCA average index is 496.10, which means it has a very strong competitiveness. This can happen because tea is Kenya's main export commodity. According to Fuady et al. (2017), Kenya's main exports come from the agricultural sector of coffee, tea, and cut flowers. Sri Lankan tea RCA Index (334.49), India (7.46), and Vietnam (5.34). Overall, the comparative competitiveness of the largest tea exporter countries in $2004-2019$ is experiencing a downward trend.

\subsection{Determining Factors of Indonesian Tea Export Volume}

Data panel regression model there are 3 types, namely Common Effect Model (CEM), Fixed Effect Model (FEM), and Random Effect Model (REM). The best models of data panel regression were selected through 3 tests, namely the Chow test, Hausman test, and Lagrange 
Multiplier (LM) test. The best model chosen in this study was the Random Effect Model (REM).

Tabel 3. Model selection test results

\begin{tabular}{ccl}
\hline \multicolumn{1}{c}{ Test } & p-value & \multicolumn{1}{c}{ Decision } \\
\hline Chow & 0.0000 & $\begin{array}{l}\text { H0 rejected, selected } \\
\text { model FEM }\end{array}$ \\
Hausman & 0.0540 & $\begin{array}{l}\text { H1 accepted, selected } \\
\text { REM model }\end{array}$ \\
LM test & 0.0000 & $\begin{array}{l}\text { H1 accepted, selected } \\
\text { REM model }\end{array}$ \\
\hline
\end{tabular}

Source: Secondary Data, 2021 (processed).

The results of the T-test showed that only the variable price of tea exports was insignificant. In contrast, the variable production of tea, the price of tea exports, the population of the destination country, the GDP per capita of the destination country, the level of trade openness of the importer country, and the inflation rate of the importer countries had a significant effect on the levels of $1 \%$ and $5 \%$. F test results show that the Prob(F-statistic) value is less than $5 \%$, meaning that independent variables simultaneously have a significant effect on dependent variables. The coefficient of determination $\left(\mathrm{R}^{2}\right)$ is 0.62 . The independent variables used in the model can explain dependent variables by $62 \%$ and the rest are explained by other variables that are not included in this research model.

Classic assumption tests performed are residual normality tests and multicollinearity tests. Residual normality tests show that residuals are distributed normally due to Jarque-Bera p-value of more than 0.05 . Multicollinearity tests showed that between independent variables of less than 0.90 . Multicollinearity will occur if the correlation value is above 0.90 (Ghozali dan Ratmono, 2017). Autocorrelation and heteroscedasticity tests were not conducted because they were completed with GLS (Generalized Least Square) (Gujarati \& Porter, 2009).

Variable production of tea has a significant effect on the export volume of Indonesian tea. The coefficient value of 2.24 means that every $1 \%$ increase in Indonesian tea production will increase the volume of Indonesian tea exports to the 7 main destinations by $2.24 \%$, ceteris paribus. The amount of production that exceeds its domestic consumption will cause a surplus of output so that the rest can be used to meet demand in the global market (Bilal \& Rizvi, 2018). This is also because of the low domestic tea consumption of only 29.2 ounces in 2018, so exporters prefer foreign markets that have great potential, especially in countries with high tea consumption.

Variable export tea prices have no significant effect on the export volume of Indonesian tea. Pratama et al. (2020) also state that products' export price does not influence exports. This is due to the better quality of Indonesian tea so that importers do not take too much issue with the price level. However, the fact that the price of Indonesian tea in the international market, especially the main export destination countries, is still very low so that many farmers have converted their land to coffee, palm oil, cocoa, and horticulture commodities (Yuliando et al., 2015).

Table 4. Panel Data Regression Estimation Results

\begin{tabular}{cccc}
\hline Variable & Coefficient & t-statistic & Prob. \\
\hline LN_PROD & $2.247800^{* *}$ & 3.361991 & 0.0010 \\
LN_PRICE & -0.054738 & -0.438026 & 0.6621 \\
LN_POP & $0.394114^{* *}$ & 5.894391 & 0.0000 \\
LN_GDP & $-0.100449^{* *}$ & -3.618577 & 0.0004 \\
LN_OPE & $0.527846^{* *}$ & 5.476645 & 0.0000 \\
INF & $0.031989^{* *}$ & 3.559926 & 0.0005 \\
C & $-35.24198^{*}$ & -2.587826 & 0.0107 \\
\hline R-squared & 0.624551 & & \\
F-statistic & 36.87373 & & \\
Prob(F-statistic) & 0.000000 & & \\
\hline Not:
\end{tabular}

Note: ** significant at the level of $1 \%,{ }^{*}$ significant at the level of $5 \%$.

Source: Secondary Data, 2021 (processed).

Variable population of destination countries has a significant influence on the volume of Indonesian tea exports. The coefficient value of 0.39 indicates that every $1 \%$ increase in the population of importer countries will impact the increase in the volume of Indonesian tea exports to 7 main destinations by $0.39 \%$, ceteris paribus. The growing population will be followed by 
increased public consumption. So if the country is not able to meet domestic demand, it will import from other countries. This will trigger an increase in exports for countries that have an edge on a commodity. This is by Alatas (2015), which states that the export destination country's population positively affects the volume of export.

Variable GDP per capita of importing countries significantly affects the volume of Indonesian tea exports. The coefficient value of 0.1 means that every $1 \%$ increase in real GDP per capita of importer countries will cause a decrease in the volume of Indonesian tea export by $-0.1 \%$, ceteris paribus. This is not by the theory of demand that a rise in revenue will cause demand for goods to increase (Parkin, 2012). GDP is one way to look at the country's wealth from the point of view of the value of goods or services produced by economic units nationally in a given period of time (Dad \& Karim, 2019). This includes assessing the prosperity of its population, which is indicated by the amount of income. The real GDP of the destination country has no effect on export volume because when the real GDP per capita of the export destination country always increases precisely the production of Indonesia's tea export volume decreases. The volume of tea exports is falling more due to the absence of tea stock to be exported due to domestic tea production, which also continues to decline.

Variable level of trade openness of importing countries has a significant influence on export volume. The coefficient value is 0.52 , meaning that every $1 \%$ increase in the level of trade openness will cause the volume of Indonesian tea exports to increase by $0.52 \%$, ceteris paribus. It is by Verter \& Bečvářová (2014) that the level of trade openness has a positive impact on exports. The level of trade openness is the ratio of exports and imports to the country's GDP value. Countries with a high level of trade openness mean the country is increasingly open to export and import activities. When the country can produce commodities efficiently, it will open export opportunities. Conversely, when a country cannot produce commodities efficiently, it would prefer to import from another country.

Variable inflation of destination countries has a significant influence on the volume of Indonesian tea exports. Any increase in importing countries' inflation by $1 \%$ will result in an increase in the volume of Indonesian tea exports to 7 major destination countries by $0.03 \%$, ceteris paribus. Inflation in a country will cause the price of imported commodities to be cheaper than domestic commodity prices, thus stimulating the increase in import volume, especially for countries that do not have the resources to produce the commodities needed. For exporters, inflation will cause production input costs to increase so that the price of products produced is also higher and will ultimately impact decreasing competitiveness and export volume (Yee et al., 2016).

\section{Conclusion}

Based on research, it can be concluded that the trend of production and export volume of Indonesian tea will decrease. Indonesia's tea production in 2024 will touch 129,492 tons and the volume of tea export is 33,141 tons. Indonesia has a very strong comparative competitiveness but still below India, Kenya, Sri Lanka, and Vietnam. Indonesia tends to be an exporter of tea to the international market at the stage of export expansion or growth stage.

Determining factors in the volume of Indonesian tea exports to the main destination countries are Indonesian tea production, the population of importer countries, real GDP per capita of importer countries, level of trade openness of importer countries, and the inflation rate of importer countries. Indonesia's tea exports, which are still at the export expansion stage or growth stage, are expected to concentrate on the export share that has been increasing. As is the case to countries in the Southeast Asia region, the volume and value of exports are relatively increased.

\section{References}

Abidin, I. S. Z., Bakar, N. A., \& Sahlan, R. (2013). The Determinants of Exports between Malaysia and the OIC Member Countries: A Gravity Model Approach. Procedia Economics and Finance, 5(13), 12-19. https://doi.org/10.1016/s22125671(13)00004-x

Alatas, A. (2015). Trend Produksi dan Ekspor Minyak Sawit (CPO) Indonesia. AGRARIS: Journal of Agribusiness and Rural Development Research, 1(2), 114-124. https://doi.org/10.18196/agr.1215

Anyanwu, J. C. (2014). Factors Affecting Economic Growth in Africa : Are There any Lessons from China? African Development Review, 26(3), 468-493. 
Bassa, Z., \& Goshu, D. (2019). Determinants of coffee export in Ethiopia: an application of co-integration and vector error correction approach. Agricultural and Resource Economics, 5(4), 32-53. https://doi.org/10.22004/ag.econ.300029

Bekele, W. T., \& Mersha, F. G. (2019). A Dynamic Panel Gravity Model Application on the Determinant Factors of Ethiopia's Coffee Export Performance. Annals of Data Science, 6(4), 787-806. https://doi.org/10.1007/s40745-019-001984

Bilal, M., \& Rizvi, S. B. (2018). Determinants of Rice Exports: An Empirical Analysis of Pakistan. Journal of Global and Scientific Issues., 7(2), 61-72.

Carvalho, A. R. de, Ribeiro, R. S. M., \& Marques, A. M. (2017). Economic development and inflation: a theoretical and empirical analysis. International Review of Applied Economics, 32(4), 546-565. https://doi.org/10.1080/02692171.2017.13 51531

Chadhir, M. (2015). Analisis faktor-faktor yang mempengaruhi ekspor teh Indonesia ke negara Inggris 1979-2012. Economics Development Analysis Journal, 4(3), 292300.

https://doi.org/doi.org/10.15294/edaj.v4i3. 14836

Content, J., \& Frenken, K. (2016). Related variety and economic development: a literature review. European Planning Studies, 24(12), 2097-2112.

https://doi.org/10.1080/09654313.2016.12 46517

Dad, A., \& Karim, A. M. (2019). A Literature Review on External Factors Affecting Export Competitiveness of Raw Woven Sector of Pakistan External Factors Exchange Rate. Malaysian Journal of Social Sciences and Humanities (MJSSH), $4(2), 51-58$.

Deka, N., \& Goswami, K. (2021). Economic sustainability of organic cultivation of Assam tea produced by small-scale growers. Sustainable Production and Consumption, 26(2021), 111-125. https://doi.org/10.1016/j.spc.2020.09.020

Directorate General of Plantations. (2019).
Indonesian Plantation Statistics. Retrieved from http://ditjenbun.pertanian.go.id/?publik asi=buku-publikasi-statistik-2018-2020

Food and Agricultural Organization [FAO]. Indonesian Tea Production. (2021). Retrieved from http://www.fao.org/

Fuady, A. H., Kresna, M., \& Hakam, S. (2017). Research Summary Crisis , Growth And Changes In Sub Sahara Africa: Evidence From Kenya. Jurnal Kajian Wilayah, 8(2), 155-162.

Ghozali, I. \& Ratmono, D. (2017). Analisis Multivariat dan Ekonometrika Teori, Konsep, dan Aplikasi dengan Eviews 10. Badan Penerbit Universitas Diponegoro, Semarang.

Gujarati, D. N., \& Porter, D. C. (2009). Basic Econometric (5th ed.). McGraw-Hill, New York.

Ishak, M., Sudarsono, Widiatmaka, \& Yahya, S. (2019). Tea Plantation Dynamic in West Java Based on Productivity and Institutional Research. MIMBAR: Jurnal Sosial Dan Pembangunan, 33(1), 191-197. https://doi.org/doi.org/10.29313/mimbar.v $33 i 1.2315$

Khaliqi, M., Gurning, H. R. H., Novanda, R. R., \& Simamora, O. N. (2020). Competitiveness Indonesia tea in international market. IOP Conference Series: Earth and Environmental Science, 454(1). https://doi.org/10.1088/17551315/454/1/012039

Krugman, P. R., Obstfeld, M., \& Melitz, M. J. (2018). International Trade Theory and Policy (11th ed.). Pearson Education Limited, United Kingdom.

Narmada, I. B., Sarasati, A., Wicaksono, S., Rezkita, F., Putra Wibawa, K. G., Hayaza, S., \& Nugraha, A. P. (2020). Phytochemical screening, antioxidant activity, functional groups and chemical element characterization analysis of (-)Epigallocatechin-3Gallate (EGCG) in East Javanese green tea methanolic extract: An experimental in vitro study. Systematic Reviews in Pharmacy, 11(5), 511-519. https://doi.org/10.31838/srp.2020.5.68 
Nayantakaningtyas, J. S., Daryanto, A., \& Saptono, I. T. (2017). Competitiveness Of Indonesian Tea In International Market. Indonesian Journal of Business and Entrepreneurship, 3(1), 14-23. https://doi.org/10.17358/IJBE.3.1.14

Ngouhouo, I., Nchofoung, T., \& Njamen Kengdo, A. A. (2021). Determinants of Trade Openness in Sub-Saharan Africa: Do Institutions Matter? International Economic Journal, 35(1), 96-119. https://doi.org/10.1080/10168737.2020.18 58323

Nugrahaningrum, Y., Zakaria, R., \& Fahma, F. (2020). Analysis of Indonesian tea competitiveness in the international market Analysis of Indonesian Tea Competitiveness in The International Market. AIP Conference Proceedings, 2217(1). https://doi.org/10.1063/5.0000810

Nurunisa, V. F., \& Baga, L. M. (2012). Analisis Daya Saing dan Strategi Pengembangan Agribisnis Teh Indonesia. Forum Agribisnis, 2(1), 33-52. https://doi.org/doi.org/10.29244/fagb.2.1.3 3-52

Parkin, M. (2012). Macroeconomics (10th ed.). Pearson Education, New York.

Paul, J., \& Dhiman, R. (2021). Three decades of export competitiveness literature: systematic review, synthesis and future research agenda. International Marketing Review, 26(4), 472-492. https://doi.org/10.1108/IMR-12-2020-0295

Pratama, A. P., Darwanto, D. H., \& Masyhuri. (2020). Indonesian Clove Competitiveness and Competitor Countries in International Market. Economics Development Analysis Journal, 2(4), 446-455. https://doi.org/doi.org/10.15294/edaj.v9i1. 38075

Pugel, T. (2016). International Economics (16th ed.). McGraw-Hill Education, United States of America.

Ramadhani, F. (2013). Daya saing teh Indonesia di pasar internasional. Economics Development Analysis Journal, 2(4), 468475.

https://doi.org/doi.org/10.15294/edaj.v2i4. 3214
Suprihatini, R. (2005). Indonesian Tea Export Competitiveness in the World, $\mathrm{S}$ Tea Market. Jurnal Agro Ekonomi, 23(1), 1-29.

Verter, N., \& Bečvářová, V. (2014). Analysis of some drivers of cocoa export in Nigeria in the era of trade liberalization. Agris OnLine Papers in Economics and Informatics, 6(4),

208-218. https://doi.org/10.22004/ag.econ.196590

Voora, V., Bermúdez, S., \& Larrea, C. (2019). Global Market Report: Tea. Sustainable commodities marketplace series 2019. International Institute For Sustainable Development (IISD), Canada. https://www.jstor.org/stable/resrep22027?s eq $=1 \#$ metadata_info_tab_contents

Wal, S. van der. (2008). Sustainability issues in the tea sector - A comparative analysis of six leading producing countries. Stichting Onderzoek Multinationale Ondernemingen (SOMO), Amsterdam. https://papers.ssrn.com/sol3/papers.cfm?ab stract $\mathrm{id}=1660434$

Wang, L. (2015). An Analysis of Trade Structure, Comparative Advantage and Complementarity of Agricultural Products between China and the Main East Asian Countries. Asian Agricultural Research, 7(5), 14-20. https://doi.org/10.22004/ag.econ.207033

Trade Statistics for International Business Development [Trademap]. (2021). Retrieved from https://www.trademap.org

United Nations Commodity Trade Statistic Database [UN Comtrade]. (2020). Retrieved from https://www.un.comtrade.org/data

Yee, L. S., WaiMun, H., Zhengyi, T., Ying, L. J., \& Xin, K. K. (2016). Determinants of Export: Empirical Study in Malaysia. Journal of International Business and Economics, 4(1), 61-75. https://doi.org/10.15640/jibe.v4n1a6

Yuliando, H., Erma, K. N., Cahyo, S. A., \& Supartono, W. (2015). The Strengthening Factors of Tea Farmer Cooperative: Case of Indonesian Tea Industry. Agriculture and Agricultural Science Procedia, 3(2015), 143-148. 
https://doi.org/10.1016/j.aaspro.2015.01.02

8

Zhi, X., Xianjin, H., Zheng, Z., \& Hong, Y. (2018). Spatio-temporal variation and the driving forces of tea production in China over the last 30 years. Journal of Geographical SciencesJournal of Geographical Sciences, 28(3), 275-290. https://doi.org/10.1007/s11442-018-1472-2 